\title{
LEARNING BASED ON ENVIRONMENT AS STIMULUS TO THINK CRITICAL IN LEARNING THE INDONESIAN LANGUAGE IN THE 3T AREA
}

Erwin $^{*}$

Muhammadiyah University of Mataram

\begin{tabular}{|c|c|}
\hline ARTICLE INFO & A B S T R ACT \\
\hline $\begin{array}{l}\text { Keyword: } \\
\text { learning, } \\
\text { environment-based, } \\
\text { critical thinking, } \\
\text { Indonesian, } \\
\text { and 3T areas }\end{array}$ & $\begin{array}{l}\text { There has been a tremendous jump in the dynamics of learning in the 21st century Era } \\
\text { today. Innovation of learning increasingly experienced development, ranging from digital, } \\
\text { online, blended, multimodal, and some other innovations created as an alternative that is } \\
\text { deemed to overcome learning difficulties in education. This paper is presented as an } \\
\text { affirmation, that there are exceptions that must be adjusted to the learner in the } 3 \mathrm{~T} \text { area, } \\
\text { due to the lack of educational infrastructure. Therefore, the innovation of environment- } \\
\text { based learning can be an alternative as a stimulus to hone students thinking crisis in } \\
\text { learning Indonesian. This paper presents some important points, namely: (1) Learning } \\
\text { Indonesian Phenomenon. (2) Problem of Indonesian Language Learning in 3T Areas. (3) } \\
\text { Environment Learning and Environmental Use in Learning. (4) Critical Thinking with } \\
\text { Environmental-Based Learning. (5) Lessons Learned in 3T Areas Using Environmental- } \\
\text { Based Learning. }\end{array}$ \\
\hline
\end{tabular}

\section{INTRODUCTION}

The Era of the 21st Century is labeled as the Age of Digital Industry which is increasingly dragging the generation to be adaptable by making the most of digital technology as a means of fulfilling the needs, it is also meant as a solution to solve educational problems (Chandra \& Suyitno, 2017). Our educational world, now trying to adopt and adapt to these developments, seems to have forgotten that Indonesia has other problems that should be taken seriously so that there is no sort of unbalanced educational arrangement between the city and the periphery that the State has labeled the Outermost, Outermost, and Disadvantaged (Area 3T).

Recognizing the limitations should be a necessity, in order to continue to clean up, but on the other side, we must continue to move to catch up. This dilemmatic condition should be a consideration for the government to give more attention to education in $3 \mathrm{~T}$ areas, especially those related to infrastructure. Thus, the discriminatory impression does not continue to emerge as a stumbling block for the development and advancement of education in this beloved country of the Unitary Republic of Indonesia. The fact shows that education in urban areas is now experiencing tremendous developments with all forms of learning innovation, while in 3T, education seems far behind. Meanwhile, the evaluation of learning is applied nationally with the same standards, whereas the learning process takes place in a much different way and facilities.

Departing from the fact of the limitations of infrastructure as described, the innovation of environment-based learning can be an alternative solution to promote and develop education for the generation of the nation (learners) in 3T area. With environmental-based learning, they can hone their critical thinking power freely in pleasant situations. With environmental-based learning, in addition to stimulating the reasoning sense of critical and fun, it also integrates the values of national character gained

\footnotetext{
" Corresponding author.

E-mail addresses: erwinpbsi@ummat.ac.id (Erwin)
}

ISSN : 2597-7385 (Online) - ISLLAC : Journal of Intensive Studies on Language, Literature, Art, and Culture is licensed under Creative Commons Attribution-ShareAlike 4.0 International License (http://creativecommons.org/licenses/BY/4.0/).

7 | ISLLAC : Journal of Intensive Studies on Language, Literature, Art, and Culture 
when interacting with the social environment, cultural environment, religious environment, educational environment, and the surrounding natural environment.

As an illustration of environment-based learning, in the context of Indonesian language learning with writing skills, it is said that "as a novice writer, students need motivation, social, knowledge, and cultural environment as inspiration to produce a writing (Djustik, 2008; Erkan \& Sabah, 2015, Raofi at all. 2014, in Challob at al. 2016). "The view actually affirms that learning motivation can increase if learners derive stimulus from social situations as an experience, knowledge gained through the environment learning, and the surrounding cultural environment.

\section{LEARNING INDONESIAN PHENOMENON}

Indonesian language learning is often considered easy and even considered unimportant, both by teachers and students. This is evident from the scheduling of Indonesian language courses that are often encountered in the last hour and students appear less enthusiastic to follow the Indonesian language lesson. While we know together, that the Indonesian language is one of the main subjects that must be taught starting from the level of early childhood to college. Indonesian Language and Literature is a unity that is packaged in Indonesian language learning materials. Thus, actually learning Indonesian language is seen as one of the important instruments to be able to realize the generation of national education characterisation.

If we look at the current conditions, there appears to be a decline in the value of characters in many language lives we encounter in the child's daily behavior. Respectful and respectful gestures, such as saying thank you, sorry, and excuse are rarely heard. While on the other hand, vulgar phrases in communication often occur. This social fact is an important task of learning Indonesian, because according to Furqon (in Majid, 2012: 45), argued that the decline in the value of character caused by two factors: First, the educational system is less emphasis on the formation of character values, but more emphasizes the development of the cognitive domain only; Second, the environmental conditions are less supportive for the development of the character itself.

The first factor we encounter in language education, generally language learning in schools is still a lot of emphasis on theories of language, rather than demanding students to speak language skilled. Less supportive environmental conditions, as well as increasing the complexity of language education. There is a general perception of society, that "the important language that others know." It has become a collective belief that Indonesian language learning is one of the aspects that can determine the future of the nation. As the saying goes "Language shows the nation". Once the importance of language in the life of society, nation and state, so it needs a policy that has implications for the development and learning of language and literature in society and educational institutions. One form of coaching that is considered the most strategic is learning Indonesian in school. Teachers' participation in language development and learning plays a very important role. Teachers become figures who become role models in language skills. Teachers are responsible for the success of language learning. For the purpose of language learning can be realized, that is 'students are able to communicate well and correctly', it is necessary knowledge and understanding of teachers related to language learning strategies that refer to the basic principles of language learning, namely contextual, functional, integrative, appreciative, and communicative.

As a concrete proof of the implementation of education as a dimension of the development of Indonesian language and literature is the issuance of the regulation by the state that the Indonesian language as the official language of the state, and one of the functions that it is cited as the language of instruction in the world of education. As stated in Law, number 24, 2009, chapter III on the language of the State, articles 25 to 45, one of them in article 25 (paragraph 3) "Bahasa Indonesia as the official language of the State serves as the official language of the State, the introduction of education, national level communication, the development of national culture ... " This is also reinforced in Law no. 20 of 2003, Article 37 (paragraphs 1 \& 2) which requires the loading of Indonesian language subjects in the curriculum of primary and secondary education, as well as higher education. In particular, the commanders even issued a policy on Indonesian language and literature development as set forth in Government Regulation, member 57, 2014, on the development, fostering, and protection of language and literature, as well as improving the function of the Indonesian language.

Thus, it is clear that the management of education in addition to requiring the role of Indonesian language is also intended to improve the skills of Indonesian language as a manifestation of the Indonesian language development efforts. Unfortunately, we have shown a fact that the generation of the nation often shows its unavailability for the presence of Indonesian language learning. This is obvious when faced with Indonesian language lessons, learners always complain of boredom, not enthusiasm, take lightly. Even the 
sad is the result of the Indonesian language test, tend to be lower than the results of other eye examinations.

The condition and phenomenon of Indonesian language learning as described above should be given special attention because the existence of Indonesian language learning is one reflection of the nationalism attitude of the nation's generation. One way that can be done to improve the motivation to learn Indonesian is to continue to create learning innovations that are not only create value but also in accordance with the context of the needs and readiness of supporting infrastructure.

\section{THE PROBLEM OF INDONESIAN LANGUAGE LEARNING IN 3T AREAS}

In general, Indonesian language learning is related to efforts to improve the four language skills, namely; listening skills of speaking, reading, and writing. This is what Dardjowidjojo (1987) says that defines, that:

The competence of language as a mastery of the system of the rules of language that really lived allows recognizing the inner structure and birth structure so as to distinguish between the correct sentence and wrong sentence, and to understand sentences that have never been heard or said before. Therefore, the establishment of language competence cannot be separated from language learning in schools, both formal and non formal schools. Simply speaking, language learning at school trains listening, speaking, reading, and writing skills. Language proficiency depends on the four components that come from the knowledge of grammar, vocabulary, and phonology or graphology (phonology or graphology).

In practice, efforts to improve these four language skills often face problems in learning in the world of formal education. Of course, the learning problem is very varied, the general problem of learning related to the competence of teachers as teaching staff, student learning motivation, supporting facilities/infrastructure learning, and other related problems. A'Ing (2015) explains that the problem or inhibiting factor of education in remote areas is; (1) lack of awareness of the importance of education, especially the support of the child, (2) lack of educational facilities and infrastructure; and (3) the location of schools far from the settlements that make it difficult to reach. Meanwhile, Sjarkawi, et al (2009) explains, that the problem or inhibiting factor of learning is caused by; (1) the teacher's academic ability is less, (2) the teacher's teaching skill is insufficient with the less curriculum, (3) the teacher's level of education is inadequate, (4) the teacher's ability to carry out the tasks according to the demand of the curriculum, (5) lack of intensive training on curriculum, (7) inadequate school facilities, (8) the environment and atmosphere of working relationships in schools are less conducive, (9) poor principals' leadership and poor committee, (10) lack of awards for outstanding teachers, (11) inadequate study time, (12) teacher salary/incentive is still small, (13) lack of support from fellow teachers and school staff, (14) number of pupils in one class too many, 15) lack of support and participation of parents. In line with the above two opinions, Sulfasyah, and Hanis (2016) states that the problem of education in remote areas is the discrimination of educators, and the means of facilities resulting in the process of learning and teaching cannot take place optimally.

Based on the problems of education and learning as described above, I would like to invite this opportunity to identify the problems of learning Indonesian in the Left, Outermost and Underdeveloped Areas (3T) based on my personal experience. I want to start with my experience while teaching in 20072010 then, in my birthplace. I teach in four schools, two private schools; MTs and MA Almutmainnah, and two State schools; SMPN 4 and SMPN 5 in Kecamatan Soromandi, Kabupaten Bima, West Nusa Tenggara Province. I teach in four schools, for two basic reasons. (1) because Indonesian teachers are less needed, and (2) because of financial needs, because the salary/incentive teaching is so small that I have to teach in many places (schools). Four schools are located in the suburbs are indeed all limitations. Some of the problems I face are: (1) the number of students in one class is very large, (2) there is no books for student handling and the supporting references are not available in the library, (3) students find it difficult to familiarize themselves with Indonesian in the school circle, even in the classroom, (4) ) there is no learning media as a supporter, either OHP, LCD, let alone internet network, so that learning takes place conventionally, (5) the time provided in learning is not sufficient, because learning only takes place with aktitas, writing and listening, (6) boredom, lack of motivation to follow the lesson, and (7) the learning is monotonous, the students tend to be passive, because only landing and listening, while the teacher dominates the learning activities. 


\section{ENVIRONMENT LEARNING AND ENVIRONMENTAL USE IN LEARNING}

The learning environment is one that can affect student's learning motivation. Hannah (2013) provides a simple illustration, that in the reality of learning, usually a large number of time students are spent in the classroom only. Therefore, the learning environment or class becomes an important place for the development of children's knowledge, in other words, the learning environment can affect the quality of student learning. Thus, the class as a learning environment should be organized and organized as well and as good as possible so that students feel happy when the learning interaction takes place.

A teacher should be aware of the context of environment-based learning because Reutzel \& Sarrah (2011) says it is important to understand, "Where are your students now and where should they be?" This suggests that in addition to the ability to engineer learning environments, teachers should also be able to take advantage of the environment as a source of learning. A teacher in a particular situation wants or wants the learning to be effective. Thus, one of the innovations that can be done by the teacher is not to make the class as the only learning environment, but to utilize the cultural, social, natural and other environments in accordance with their interests, "because in a learning situation usually shows a tendency , that students will learn more effectively when they are interested in their learning environment "(Darlene Parner, 2004).

If we consider the above opinions, we should agree that learning must be created in order to be effective, comfortable and enjoyable. Mark (2013) says that the modern learning environment can produce quality learning through a combination of elements as follows.

1) Personal learning; no two individuals learn in the same way, nor do they hire the same prior knowledge as a learning experience. How to learn is a uniqueness and our identity.

2) The social reality of learning; collaboration, tutorials, and feedback in learning when students work together to generate an understanding of the material under discussion.

3) Learning motivation; the importance of the basic knowledge that affects individuals in facing challenges, managing speed, and understanding of content and context.

4) Learning must be initiated by the students themselves; usually, when a student starts a learning or exploratory experience, they learn more.

5) Learning related to the physical world and authentic context; children learn to interact with others and the physical world.

If so, the environment-based learning and learning environment or the use of the environment in learning should consider the supporting aspects as mentioned by Mark above, so that learning innovation can affect students' learning motivation in the learning process and ultimately impact on improving the quality and competence of the language.

\section{CRITICAL THINKING WITH ENVIRONMENTAL-BASED LEARNING}

The term 'Critical thinking' first appeared in academic and literary circles in the mid-twenties. In 1941, Edward M. Glaser emphasized that critical thinking is the search for evidence to support (or discredit) beliefs or arguments. Even before Glaser used the term 'Critical Thinking' to be true in human history. The Greek philosopher Socrates, an eyewitness who set out to question the everyday convictions and to arrive at the truth on the basis of tangible evidence. Thus, then at a very basic level, critical thinking is about finding out if something is true, partly true or not true at all (Hughes, 2014: 1).

"Critical thinking" is actually a term many people have used in diverse ways. Thus, the concept of critical thinking can be translated as one form of awareness of the truth obtained through the process of thinking. In harmony with that, Cromley (1998: 137) argues, that critical thinking can mean good thinking to avoid mistakes. Thus, if contextualized in learning, then the rationale of thinking is the fact that learners are getting information from their own experiences to understand what they read, see and hear.

Huitt (1998), Rezaei, et al (2011) stated that in the information age, critical thinking plays an important role in determining one's success in life. He goes on to say, that the movement toward the information age has shifted to the attention of good thinking as an essential element of the success of life. In line with that opinion, Chaffee (1985), Paul (1995), Rezaei, et al (2011) mentioned that improving students' critical thinking skills is the core of meaningful education.

In the context of Indonesian language learning with an environment-based approach, in fact, critical thinking becomes the basis for students to develop self-competence by utilizing the surrounding environment as a source that can stimulate their critical reason. Conversely, with environmental-based learning actually provides space for learners to process their logic freely by connecting between the theoretical concepts and the factual reality of the environment experienced, observed, and heard around 
them critically. Critical thinking in learning environment-based Indonesian language is actually realized as follows.

1) As a basis for formulating the relationship of theoretical concepts with environmental reality so as not to give rise to speculative assumptions.

2) To be able to select information and select topics relevant to the learning environment.

3) Ability to question opinions, to scrutinize problems, to argue and to convey ideas.

4) Produce objective reflective reasoning.

5) Can analyze the material, formulate an opinion about a thing and can support the argumentation.

6) Make students more independent and confident.

7) Helps to open broader insights or perspectives about a problem with different angles.

\section{LESSONS LEARNED IN 3T AREAS USING ENVIRONMENTAL-BASED LEARNING Concept of Ideas}

Based on a number of considerations and facts faced by the world of education, especially learning Indonesian in the forefront, outermost, and underdeveloped (3T areas), then environmentbased learning can be a concrete solution alternative. Consideration regarding the use of environment as a learning resource of Indonesian language, besides to overcome the problem of facilities and infrastructure, also because of the potential of environment in 3T area, which is possible. There are a number of advantages and advantages in learning environment-based Indonesian language, among others:

1) It does not cost;

2) the potential of the environment can be accessed freely and safely;

3) learning takes place with great fun;

4) student learning motivation has increased;

5) the teacher is not seen as a frightening figure, but is respected for his position in learning as a facilitator;

6) the interaction of learning becomes more active;

7) students become more critical and very enthusiastic to follow Indonesian lessons; and

8) students more easily understand the lesson, because it directly interacts with the environment. this is because learning is not textual, but is contextual.

\section{Implementation of Environment-Based Learning Indonesian Language}

Environmental-based learning has a distinctive feature as a differentiator from other learning innovations. The innovation of environment-based learning is a learning that involves environmental aspects at each stage of learning, both in planning, implementation, and evaluation of learning. For example, the following is the scenario of organizing students in environment-based learning as part of the implementation stages of learning environment-based Indonesian language with writing learning materials.

1) Students involvement in active learning activities

Students are expected to participate actively in learning so that matters relating to learning materials to write can be obtained properly. Less clear things can be asked, in order to get a response from the teacher. Furthermore, students are asked to define or propose writing learning topics about the environment around the school as a source of learning.

2) Division of groups and assignments to students fairly Students are divided into several small groups by considering the ability of each member of the group varies. Once formed groups, each assigned to write with environmental topics that have been determined together.

3) Provision of motivation to students

Furthermore, students are motivated by teachers to write based on knowledge, experience, and observations in the learning environment.

4) Interaction with the environment

In the interaction with the environment, students make a visit with the intention to observe the environment, to record everything that happens as a reference development of ideas in learning to write by seeing, listening, and taking notes.

5) Development of discussion and cooperation among students

After each student writes his or her ideas and the results of the recording, they return to the class to continue the group discussion to re-write the writing. Improved spelling, punctuation, diction, sentence patterns, and the fulfillment of elements of cohesion and coherence.

11 | ISLLAC : Journal of Intensive Studies on Language, Literature, Art, and Culture 
6) Improve the papers

The teacher instructs the students to collect the papers assigned at the end of the meeting to be assessed or evaluated. Before the meeting ends the teacher motivates students to continue to improve their writing skills by continuing to practice and should not hesitate to let alone fear to put ideas in writing. Furthermore, students convey opinions, ideas, or questions about their learning experiences.

7) Closing

Learning ends, teachers deliver messages that are motivating and say the closing.

\section{CONCLUSION}

Based on the above description, it can be concluded that the learning environment-based Indonesian language is very suitable for use in the Outside, Outermost and Underdeveloped Areas (3T), because then the students will become more critical, more comfortable, active, and productive so that learning will more effective.

1) Students become more critical, as they can freely explore their failures by accessing knowledge through the environment, as well as integrating theoretical concepts with their factual environmental situations.

2) The situation of learning feels comfortable for students because the teacher does not dominate the process of learning and learning does not seem to force students to think about milk which is not real (absurd).

3) The learning situation becomes active because students can interact directly not only with teachers and students but with the surrounding environment. They can freely and enthusiastically in the learning proser.

4) Students as learning subjects become more productive, because they can freely pour ideas and ideas into writing based on the knowledge, experience, and environmental observers made with their friends, and discuss it in the dynamics of group learning.

As the end of this article, I would like to convey that this paper is not the result of research, but the elaboration of the author's critical thought from the theoretical concepts with the empirical facts experienced by the author. Therefore, criticism and input from various parties are desirable that this paper can be fixed properly.

\section{REFERENCES}

A'ing, A. (2015). Studi tentang Pembangunan Bidang Pendidikan daerah Perbatasan Kecamatan Kayan Hulu Kabupaten Malinau. E-Joernal Pemerintahan Integratif. Volume 3, No. 4, hal. 545-557. ejurnal.pin.or.id.

Chaffee. (1985). Thinking Critically. Boston: Houghton Miftlin Company.

Chandra, N. E., \& Suyitno, I. (2017). The Representation of Character Education on Teachers' Utterances in Early Childhood Learning. ISLLAC: Journal of Intensive Studies on Language, Literature, Art, and Culture, 1(2), 53-63.

Cromley, Jennifer. 1998. Learning to Think, Learning to Learn: What The Science of Thinking and Learning Has to Offer Adult Adication. Amerika: Literacy Leader Fellow. http://www.nifl.gov/activities/ fllwname.htm.

Dardjowidjojo, Seonjono. (1987). Linguistik Teori dan Terapan. Jakarta; PT Arcan Unika Atma Jaya.

Hannah, Ryan. (2013). "The Effect of Classroom Environment on Student Learning" Honors Theses. Paper 2375. http://scholarworks.wmich.edu/honors_theses.

Huitt, W. (1998). Critical Thinking: An Overview. Educational Psychology Interactive. Retrieved March, 2009, from http://chiron.valdostaedu/whuitt/col/cogsys/critthnk.htm Leadership, 42(8), 36-39.

Majid, A. (2012). Pendidikan Karakter Perspektif Islam. Bandung: Remaja Rosdakarya.

Mark, O. (2013). Modern Learning Environments. Core Education's White Pepers.

Paul, R. W. (1995). Bloom's Taxonomy and Critical Thingking Intervention. Educational

Reutzel, D. Ray, and Sarah Clark. (2011). Organizing Literacy Classrooms for Effektif Instruction: A Survival Guede. The Reading Teacher, Vol. 65 Issue 2. DOI: 10.1002/TRTR.01013.

12 | ISLLAC : Journal of Intensive Studies on Language, Literature, Art, and Culture 
Rezaei, S. et al. (2011). Critical Thinking in Language Education. Journal of Language Teaching and Research, Vol. 2, No. 4, pp. 769-777, July 2011 (c) 2011. ACADEMY PUBLISHER Manufactured in Finland. doi:10.4304/jltr.2.4.769-7

Sjarkawi, et al. (2009). Analisis Permasalahan dan Kebutuahan Guru SMA Negeri Daerah Terpencil dalam rangka Implementasi Kurikulum Tingkat satuan Pembelajaran (KTSP) di Provinsi Jambi. Jurnal Penelitian Universitas Jambi Seri Humaniora. Volume 11, No. 2, pp. 61-67.

Sulfasyah, and Hanis. (2016). Diskriminasi Pendidikan Masyarakat Terpencil. Jurnal Equilibrium Pendidikan Sosiologi. Volume IV, No. 2, pp. 203-212.

13 | ISLLAC : Journal of Intensive Studies on Language, Literature, Art, and Culture 